\title{
If school walls could talk: A mixed-method study of physical space marking in promoting multiculturalism
}

\author{
Margareta Jelić $^{1}$ (D) - Dinka Čorkalo Biruški ${ }^{1}$ (D) - Blaž Rebernjak ${ }^{1}$ (D)
}

Accepted: 23 September 2020 / Published online: 7 October 2020

(C) The Author(s) 2020

\begin{abstract}
Combining two qualitative and a quantitative method, we explored whether school's physical environment promotes multicultural values or reflects intergroup climate in two multiethnic communities in Croatia. Croatia offers unique context for this study because minority youth from two ethnic groups use their right on minority language education and hence attend separate minority schools. Results show that the representation of ethnic symbols in schools is a reflection of inter-ethnic relations in the specific intergroup context. Specifically, ethnic symbols are overrepresented in the post-conflict context compared to the more harmonious multi-ethnic community. In harmonious intergroup context, multiculturality is promoted by emphasizing common identity, and by giving space to symbols of both minority and majority group. However, in the conflicted intergroup setting we found overrepresentation of symbols emphasizing intergroup differences. Results of focus groups as well as of the quantitative survey confirm that schools physical environment reflects intergroup relations in each community.
\end{abstract}

Keywords school's physical environment $\cdot$ Multi-ethnic communities $\cdot$ Mixed methods $\cdot$ Ethnic symbols $\cdot$ Multiculturalism

\section{Introduction}

The importance of the social context in which ethnic identities are formed and negotiated has been emphasized by Self-Categorization Theory (Turner et al. 1994) and Bronfenbrenner's (1994) Ecological Systems Theory. In multiethnic settings where ethnic minorities practice their right to education in their mother tongue, schools may serve as the key institution for (re) constructing, preserving, and enhancing ethnic identities of minority and majority youth. Although research has identified several school factors influencing ethnic identity expression, such as ethnic composition of the school (Brown 2017; Donohue 2020), school values of multiculturalism (Brown and Bigler 2002) and school climate (Brown 2017; RivasDrake et al. 2009; Aldridge et al. 2016), the role of school physical environment is still under-investigated topic. Because schools exist in specific cultural and intergroup

Margareta Jelić

mjelic@ffzg.hr

1 Department of Psychology, Faculty of Humanities and Social Sciences, University of Zagreb, Ivana Lučića 3, Zagreb 10000, Croatia contexts, different current and historical patterns of minority-majority relations are also likely to be reflected in the school's physical environment. Therefore, in this complex mixed-method study using systematic observation and focus group discussions as well as quantitative survey data, we explored two multiethnic communities in Croatia in order to investigate whether school (physical) environment plays a role in promoting (or impeding) multiculturalism.

A specific context of the study is provided by the two majority-minority contexts in Croatia. Both contexts are multiethnic and in both of them minority youth attend separate classes or separate minority schools in their respective languages. If minority students attend separate classes, their majority Croat peers go to separate classes in Croatian language; if the minority schooling is organized in separate minority schools, the majority students go to separate schools in Croatian language. Hence, this specific schooling practice aimed to preserve minority identities allows us to explore whether schools capitalize on the multiethnic context and promote multicultural values or if the schools are oriented primarily towards preserving the identity of the group that is dominant within the school and thus promote ethnic exclusivity rather than multiculturalism. Furthermore, we also explore the hypothesis that potential differences in the ways 
multiculturality is promoted in schools in different regions are mere reflection of interethnic relations in each context. We further present the main features of each region.

\section{A Brief Overview of the Minority Education in the Two Multiethnic Contexts in Croatia}

As a part of the regular public educational system in the Republic of Croatia, three basic models of schooling are offered to members of national minority groups who want to exercise their right of education in their mother tongue. First, model A implies that all classes are provided in language and script (where relevant) of a given national minority. This form of minority education is organized in separate (minority) schools or in separate classes in Croatian schools. As with other models of minority schooling, Croatian language learning is mandatory. The minority schools practicing this particular model were the research site of the present study. Second, model B assumes that science subjects are taught in Croatian while the so called "national group of subjects" (i. e. language, history, geography and arts) are taught in the language and script of the national minority. Third, model $\mathrm{C}$ is a program of nurturing mother tongue and culture in a form of having extra hours in language, literature, history, geography and art of the national minority. These classes are organized in addition to the regular school program in Croatian language.

For the present paper two minority groups are especially relevant since they have very different traditions of practicing minority education: Italians and Serbs. Thus our study was situated in two traditionally multiethnic regions in Croatia where a single minority has been the most prominent for a variety of historical and cultural reasons (Jelić et al. 2020) the town of Vukovar (57,4\% Croats, $34,9 \%$ of Serbs, and the rest are other minorities) in eastern part of Croatia and the town of Buje (48,7\% Croats, 24,33\% Italians and the rest are other minorities) in the Istrian peninsula.

The town of Vukovar became notorious for the war between Croats and Serbs in the 90's and a difficult process of post-war community reconstruction with ethnic divide between the former conflicting groups being its most prominent outcome (Čorkalo Biruški and Ajduković 2009). Before the war Vukovar was an affluent multiethnic community with Croatian majority and more than twenty other ethnic groups. However, after the war the town became ethnically divided community and in the changed political circumstances Serbs gained the status of a "new ethnic minority" (see Mesic and Baranovic 2005). The war and its aftermath led to a community burdened with consequences of destruction, high victimization and broken social ties. Though very similar in language they speak and in many cultural traditions (except religion; i. e. Croats are mainly Catholics and Serbs follow mainly orthodox tradition) the violent conflict between Croats and
Serbs and the post-conflict processes loaded by the past grievances have created an atmosphere of a strong identity competition where commonalities are highly ignored and search for (optimal) distinctiveness shapes post-conflict formation and transformation of Croat and Serb identity (Brewer 1991). Hence, collective rights aiming to preserve ethnic identity and culture became a highly significant issue for the Serbian minority after the 90's war. Our second research context is quite different. Istrian peninsula together with the town of Buje is a fairly wealthy region, focusing mostly on tourism. Although Croats and Italians speak different languages and have history of conflict dating back mostly to the WW2, decades of living together have created a fairly stable and prosperous multiethnic region with many inhabitants being bilingual. Special rights of Italian community in Istria (such as bilingualism) are also protected by the Statute of Istrian County. Schooling in Italian language has a long history in Istria and Italian was even taught as a language of the region in Istrian high schools (i.e. a form of teaching in which the language of a national minority is taught as an obligatory second language in majority schools). Nowadays a number of Croats attend Italian schools in Istria.

However, whilst providing protection for minority groups, such minority policies may also serve to emphasize intergroup boundaries (Kymlicka 1995). Although the value underlying minority schooling is multiculturalism, and research showed that multicultural experiences are important predictors of cultural values that emphasize the importance of socialization (Donohue 2020), the current system of minority schooling could also be regarded as enhancing separation of youth from the two ethnic groups, and is a source of intergroup tensions especially in Vukovar with its complex post-war processes of social reconstruction (Čorkalo Biruški and Ajduković 2007). Hence, our two research contexts differ greatly in majorityminority dynamics. While Croat-Italian context have been fairly harmonious and multiculturalism is a source of pride in both majority and minority (e. g. Čorkalo Biruški et al. 2019; Jelić et al. 2014), the Croat-Serbian context is a postconflict community where the majority-minority dynamic has been determined by the recent past and ethnic divide is a major characteristic of social relations (e. g. Čorkalo Biruški and Ajdukovic 2012).

\section{How School Physical Environment Can Affect (or Reflect) Intergroup Relations}

Based on an ecological view of environmental influences on people's attitudes and behavior, we hypothesized that the physical environment of schools would show effects on children's intergroup relations. Indeed, research has shown that physical environment can affect people's behaviour. For example, physical environment and its layout can affect 
employee behaviour in the workplace and hence their productivity (McGuire and McLaren 2007; Brill 1992). It was also shown that physical aspects of the work environment affect both job performance and job satisfaction (Brill et al. 1985; Clements-Croome 2000; Davis 1984; Dolden and Ward 1986; Newsham, Veitch, Charles, Clinton, Marquardt, Bradley, Shaw \& Readon, 2004; Stallworth and Kleiner 1996; Vischer 2007). Furthermore, studies that focused on leisure time found evidence that physical environment can have an impact on emotions, satisfaction and behavior (Ali and Amin 2014). For example, attractive and easily accessible environments may foster physical activity and thus change our habits and behavior (Carnegie et al. 2002). But physical environments can also shape our values and attitudes. Innovatively designed physical environments not only foster innovation and creativity at work (Ilozor et al. 2002; Lee 2006; Lee and Brand 2005; Mitchell McCoy and Evans 2002), but also shape a diverse set of values such as collaboration, openness, and sustainability (Oksanen and Ståhle 2013). Lastly, physical environment is a part of our culture but it can also shape our culture.

Culture is usually regarded as the most important element of human communities and one can observe cultural changes through time. Nevertheless, rarely does research address the issue of the impact of urban physical aspects on the culture, as culture seems a more distant aspect of human functioning and we are often ignorant of its impact on our attitudes and behaviour. Still, Habib and Khastoo (2014) have found that some social behaviors change when affected by urban physical aspects (e.g. relationship between enclosure and the speed of movement) and that physical aspects of the neighborhood affect the culture in the long run (e.g. children's playing). They argue that physical aspects probably affect the behaviors and these changes lead to consistent behaviors and constant choices for people's lifestyle that eventually forms the culture.

Thus it is only natural to expect that a school environment as a place where children spend most of their time and where socialization with other children takes place can have a strong impact on their intergroup attitudes and behavior. The idea of analyzing school physical environment as a proxy of school cultural climate and norms is not as far-fetched as it might seem given that some studies already showed that ideologies are reflected in cultural products. For example, Plaut et al. (2012) confirmed that the local context has an important impact on self-construal because it reflects local ideas, norms and products. Furthermore, the effect of the physical environment on the aesthetic experience of art was confirmed in a recent study in which respondents viewed art installations in either the art gallery context or the classroom (Szubielska et al. 2019). Some studies already confirmed that both social and physical environments show independent and interactive effects on children's intergroup attitudes for preschool children (Gubbels et al. 2011). We move further to explore the link between a school's physical environment and children's group identity, intergroup attitudes and multicultural values.

School's physical environment is mostly studied in the context of promoting or impeding the learning process and less in the context of promoting values attached to group belonging, such as multiculturalism, regionalism or nationalism. At the same time, physical environment can also be an important indicator of intergroup relations. For example, in a yearlong ethnographic study, Lewis (2001) analyzed school practices in order to differentiate between the explicit and the "hidden" curriculum offered in school. Although all community members consistently denied the local salience of race, various racialized practices were present and had a direct impact on students of color at the school as a "hidden" curriculum of race. One way to explore the hidden curriculum is by analyzing school décor and cultural artifacts in school that can make one's ethnic or religious identity irrelevant or very salient. One such attempt was made by IsikErcan (2014) in a qualitative case study analyzing how Turkish-American children negotiate their religious identities in school settings. Using data from various sources - interviews, participant observations and cultural artifacts -she showed that Turkish-Muslim children in elementary and middle school choose strategies that either make their religious identities invisible, or try to find innovative ways to negotiate their identities in such context. Thus, schools seem to play an important role in identity formation and in shaping values and narratives about it, both directly and indirectly.

National identity has to be learnt and national symbols play a crucial role in the construction of ethnic or national identity. Billig (1995-2004) points out that nations are daily reproduced through banal, familiar and constant reminders of nationhood (i.e.symbols) that are not consciously registered but are therefore efficient. According to Kolst (2006) national symbols (i.e. flags, coats of arms, national anthems) are the key instruments in nation-building and nation-maintenance. The ,ethno-symbolism "theory (Smith 2009) suggests that national symbols, myths, values, and memories of the group derived from mythical ethno-history can be unifying not only in established nation-states, but also in new and fragile multicultural states. However, research shows that individuals from different cultural or ethnic groups perceive graphic symbols differently (Huer 2000; Chu 2003). Thus, although the role of national symbols is to unify the nations, they can also play a divisive role when conflicted ethnic groups hold different narratives of the past. Kolst (2006) argues that the divisiveness vs. unifying potential of new state symbols is a function of what and whom they are being associated with. If a symbol is perceived as belonging to one ethnic group more than another, the other group will not accept it as their own and will search for ethnic symbols they can associate with. The comparison of national symbols in one new state (Bosnia), one newly reconfigured state (Russia) and one established nation-state 
(Norway) showed that it takes time to accept new state symbols but also that the divisions in society come first, and disagreements over state symbols are a function of these divisions (Kolst 2006). Thus in multicultural settings national and ethnic symbols can play either unifying or divisive role depending on the context, i.e. on the intergroup relations of particular ethnic groups. In multi-ethnic contexts of our study the same symbols may play unifying role in harmonious context and divisive role in conflicted context where symbols can be used to highlight differences to the specific outgroup (Bucholtz 2011) or as a form of resistance or counter-culture, as often found in the youth culture field (Johansson and Lalander 2012). Indeed, research has shown that the majority ethnic group is not homogenous with regard to the attitudes towards multiculturalism. It might depend on the perceived intergroup relations in a given context, as suggested by a recent study that confirmed the effect of perceived intergroup competition on majority adolescents' perceived threat from two relevant minority groups (Constantin and Cuadrado 2019). Additionally, a study of ideological attitudes of the same majority group in two multiethnic settings in Croatia in Istria and in Vukovar - showed that Croats in Istria have a far more positive attitude toward multiculturalism than Croats in Vukovar (Jelić et al. 2014). Thus, we wanted to explore if such different majority-minority relations are reflected in decoration of physical space in local schools.

However, the question remains which symbols should be analyzed as national and/or ethnic. Jaskulowski (2016) emphasized the central position of the flag in nationalism. Furthermore, feelings of national belonging are positively related to participation in national commemorations hence confirming the selection hypothesis (de Regt 2018). Wiltgren (2014) claims that ethnicity research often covers linguistic markers of ethnic identity while the area of consumption of nationalism, in the form of objects featuring national, ethnic and religious symbols, is under-investigated topic. In his year-long study in a junior high school, he documented ways in which minority group students handle material artefacts and the meaning they ascribe to these symbols.

A recent qualitative study conducted in Croatia yielded 27 groups of Croatian national symbols (Trako Poljak 2016). Qualitative data collected via in-depth interviews showed that participants distinguish between several categories of symbols in Croatia: official state symbols (flag, anthem, and coat of arms), cultural symbols, historical symbols, Homeland War (with special emphasis on Vukovar), local place of living, and Catholicism. Additionally, many interviewees mentioned successful Croats, such as scientists, sportsmen or important historical figures. Geography (especially territorial borders and shape of the country) was also spontaneously mentioned as an important symbol of Croatia. This study was the first to use the "bottom-up" approach in exploring the role of "ordinary" members of a national collective as the active participants in the construction of national identities. However, it neglected to analyze ethnic and national symbols from the ethnic minority perspective. To our knowledge, no such study was conducted in Croatian society thus far and in other contexts they are very scarce. For example, a study focused on Croatian minority in Austria analyzed preservation of identity of Burgenland Croats (Ščukanec 2015). The findings pointed to the importance of everyday usage of mother tongue and traditional Croatian customs in preserving Croatian identity. These findings are in line with Kornfeind (2001) who emphasized the importance of language, its status and prestige in society, for preserving one's identity. Another important factor for the identity of Burgenland Croats was the relation to the "old homeland".

Finally, a recent study on ethnic preferences and attitudes in Great Britain suggests that ethnic identity is more pronounced in mixed rather than segregated neighborhoods (Bisin et al. 2016). Moreover, authors argue that in ethnically diverse societies two distinct motivational processes - cultural conformity and cultural distinctiveness - play a role in identity formation of minority group members. When cultural conformity is at work, ethnic identity is reduced by assimilation. Conversely, when cultural distinction is a motivational force, ethnic minorities try to retain their own distinctive cultural heritage. But what decides which motivational force will take the lead? For ethnic groups, especially for ethnic minorities, ethnic identity is tied to their perception of the group status in the society (Verkuyten 2004). If the minority's cultural and ethnic identity is acknowledged and treated with respect, they should have no trouble integrating into the society. Cultural distinctiveness is then regarded as an asset and multiculturality is welcomed. However, if minority group members feel they are discriminated against based on their cultural and/or ethnic identity, they can either give up their ethnic identity and assimilate or feel threatened and thus identify more strongly with their ethnic group.

Research conducted thus far suggests that, although we often call certain societies either multicultural and accepting or culturally intolerant and closed, different minorities within the same society might have different perspectives on how they are treated and hence which status they have in a specific society. Their perspective will depend on the history of conflict, the status that a specific minority has in the society, the changes in the minority status, as well as on their experiences with discrimination.

\section{Study Aims}

Across three studies we wanted to explore differences in the representation of ethnic symbols in schools physical space in two different multiethnic regions in Croatia and investigate whether schools' physical environment would reflect 
community norms regarding intergroup relations and promotion of multiculturalism. Thus, we focused on the presence of ethnic symbols (study 1), awareness and perceptions of schools routines (study 2), and intergroup attitudes (study 3 ).

In order to answer our research questions we used systematic observations of schools, followed by focus group discussions with students from each group, and quantitative survey of intergroup attitudes with adolescents from sixth and eighth grade of primary schools (age 12-15) and second grade of secondary schools (age 16-17). Combining qualitative and quantitative methods in the unique context of two Croatian multiethnic regions where minority students (Italians and Serbs) exercise their right for schooling in their mother tongue separately from their majority peers (Croats), we hope to offer better insight in the role of ethnic symbols in schools.

\section{Study 1}

The aim of study 1 was twofold; Firstly, our aim was to explore differences in the average amount of ethnic symbols in the two research contexts, as well as differences in the representation of specific categories of symbols emphasizing either multicultural values (i.e. equal representation of two ethnic groups and similarities between them) or group exclusivity (by emphasizing intergroup differences). Secondly, we explored potential differences between elementary schools and high schools in representation of ethnic group symbols in the school space.

We expected differences between regions, as Istria is known for its' multiculturalism and openness whereas the town of Vukovar, in spite of being a home for many ethnic groups, lives its post-conflict life under a burden of Croat-Serb ethnic divide. Thus, we hypothesized that there would be significantly less ethnic symbols in schools in Istria than in Vukovar. We further expected more multicultural messages in Istria that would be observable by emphasizing regional symbols, common for both minority and majority groups. We also expected more messages of ethnic exclusivity, i.e. emphasizing ethnic symbols in schools, in Vukovar region pregnant with unresolved intergroup conflict. Furthermore, we expected more ethnic symbols in primary than in secondary schools, as high schools are more focused on providing knowledge than identity development.

\section{Method}

\section{Sample}

We focused our study on two multiethnic settings in Croatia where minority students (Italians and Serbs) exercise their right for schooling in their mother tongue. Hence they attend separate schools or classes apart from their majority peers
(Croats). As Buje is somewhat smaller town than Vukovar, we included both elementary schools and both secondary schools that exist in Buje and than chose two elementary schools in Vukovar from different parts of the town. Unfortunately we managed to include only one highschool from Vukovar. Thus our final sample included 7 schools in the previously mentioned two multiethnic towns. We visited 4 elementary ( 2 in each town) and 3 high schools ( 2 in Buje and 1 in Vukovar) representative for majority and minority education in respective settings.

\section{Procedure}

Using systematic observation of school physical space, we collected data on representation of minority and majority ethnic symbols in all 7 schools. Two independent observers visited several areas in each school - school's entrance, teachers' room, main hall, selected classrooms (classrooms where ethnically relevant school subjects, such as history, geography, music, art, mother tongue, and religious education are taught). In each school we looked for ingroup symbols, as well as symbols of other aspects of social identity (such as religious symbols, regional symbols, school symbols etc.). Each room was photographed and ingroup symbols were registered in the prepared checklist indicating if the particular symbol was present or not, and how prominently it was displayed among similar others. For the purpose of observation we predetermined symbols we were looking for on the walls (based on literature and field data from pilot visits to several schools) and 10 preliminary categories of ethnic symbols were identified: symbols of the state/national symbols, mother tongue symbols, cultural heritage, religious symbols, prominent historical figures, prominent contemporary figures, landscapes and places, historical geographical maps, home region symbols, and school life. The checklist also allowed for adding new symbols and making comments about any peculiarities when relevant. After observing various classrooms and other schools spaces each observer assessed on a 5-point scale as to what extent ethnic symbols (compared to nonethnic ones) were represented in the school, from 1 (ethnic symbols are not represented; there are only non-ethnic symbols in the school) to 5 (ethic symbols are represented in high degree; ethnic symbols dominate in the school space).

\section{Data Analysis}

After systematic observations of all schools, two independent coders coded the complete list of symbols into categories and categorizations of symbols resulted in almost $100 \%$ agreement. Few cases of different categorization were resolved through discussion among the observers. Final categorization yielded groups of ethnic symbols: state symbols, mother tongue symbols, cultural heritage, religious symbols, 
historical figures, region symbols, and school symbols. Each category was additionally categorized as referring to either majority or minority ethnic group except the last two (regional symbols and symbols depicting school life) that refer to a common identity. Regional symbols included symbols of their hometown or somewhat wider region (Istrian peninsula for the schools from Buje or symbols of Slavonija County for those from Vukovar). School symbols refer to markings that depict school's history, celebrations of the School Day, photos of school excursions etc. Finally, contextual differences in representation of specific category of ethnic symbols in the school space were analyzed.

\section{Results}

\section{Representation of Various Ethnic Symbols in Schools}

Results showed that the quantity of ethnic symbols varies greatly depending on the context, i.e. on average twice as many ethnic symbols were present in schools in Vukovar than in Buje. In line with expectations, results of systematic observation suggest that presence of ethnic symbols in schools varies depending on the settings, from moderately present in the harmonious intergroup settings to highly present in the post-conflict intergroup setting. While the average number of ethnic symbols per school registered in the town of Buje (Croatian-Italian context) was 14.25, in Vukovar (CroatianSerbian context) the average number of ethnic symbols per school was as high as 28.67. The fact that in Vukovar we found twice as many ethnic symbols in schools indicates that in the post-conflict context the differences between the groups may be further enhanced in school settings, which is in line with our hypothesis.

However, it is also possible that some schools simply decorate their space more than others. To further test our hypothesis that in Vukovar there are much more ethnic symbols than in Buje, we analyzed assessment of the school space provided by the observers. To reiterate, after systematic observation of the ethnic symbols in the school each observer estimated the "ethnicization" of the school space, i. e. the prevalence of ethnic symbols over those non-ethnic was assessed using 1 to 5 scale. Higher number indicated higher presence of ethnic (compared to non-ethnic) symbols in the school. Results confirm significant differences between Buje $(\mathrm{M}=3.1, \mathrm{SD}=$ 1.41) and Vukovar $(\mathrm{M}=4.2, \mathrm{SD}=0.88)$ in assessment of the schools as being loaded with ethnic symbols $(\mathrm{t}=4.58, \mathrm{df}=$ $53.7, p<.001 ; \mathrm{d}=1.03)$. This strong effect suggests large differences between the two communities in types of messages being sent from the school walls. The average assessment higher than 4 suggests strongly ethnicized school environment where even decoration of the schools sends a clear message to students about importance of ethnicity as an identity marker.
In Buje the presence of ethnic symbols seems smaller, and the average estimates suggest that ethnic symbols are equally present as other, non-ethnic, symbols. Thus, it appears that schools in Buje decorate schools for various occasions, and with many different symbols, making ethnic symbols just one among many others.

\section{Differences in Ethnic Symbols Presence in Elementary and Secondary Schools}

When comparing elementary and secondary school we expected more ethnic symbols in elementary schools when children first learn of groups and social identities, belonging to different ethnicities and nations, as well as states. In secondary schools more emphasis is usually put on reaching educational curriculum outcomes and less on other goals. Interestingly, comparison of the total number of ethnic symbols in primary and in secondary schools showed different trends in Buje and in Vukovar. Whereas the average number of ethnic symbols is greater in primary (12.5) than in secondary schools in Buje (7.5), the findings were quite the opposite for schools in Vukovar (23 in primary and 40 in secondary school). Furthermore, when we compared the number of ethnic symbols in primary schools, the difference between the two contexts was moderate (twice as many symbols on average in Vukovar compared to Buje). However, in secondary schools the results tell a different story. We found high overrepresentation of ethnic symbols in secondary schools in post-conflict Vukovar compared to more peaceful Buje (where the average number of ethnic symbols per school is low). The ratio in secondary schools is $1: 5$, indicating much stronger influence on adolescents in Vukovar schools to form and enhance their ethnic identity.

We also analyzed and compared the representation of specific categories of ethnic symbols in the two contexts. Taking into account the aspects that form ethnic identity in Croatia, we expected higher representation of both majority (Croats) and minority (Serbs) ethnic symbols in Vukovar compared to more harmonious context of Buje. Specifically, we expected more language and religious symbols as well as more symbols referring to Vukovar during the 1991-1995 war in Vukovar than in Buje.

Profiles presented in Fig. 1 show that results confirm our hypotheses. In multiethnic communities in Croatia ethnic identification in school is indeed promoted via school's physical environment and mostly through symbols of cultural heritage, famous same-ethnic figures, religious symbols and language of one's ethnic group.

Comparison of the profiles in Buje and Vukovar showed differences between primary and secondary schools in how ethnicity was represented on the school walls. In primary schools in Vukovar there was the highest presence of symbols of majority cultural heritage, but also majority mother tongue 


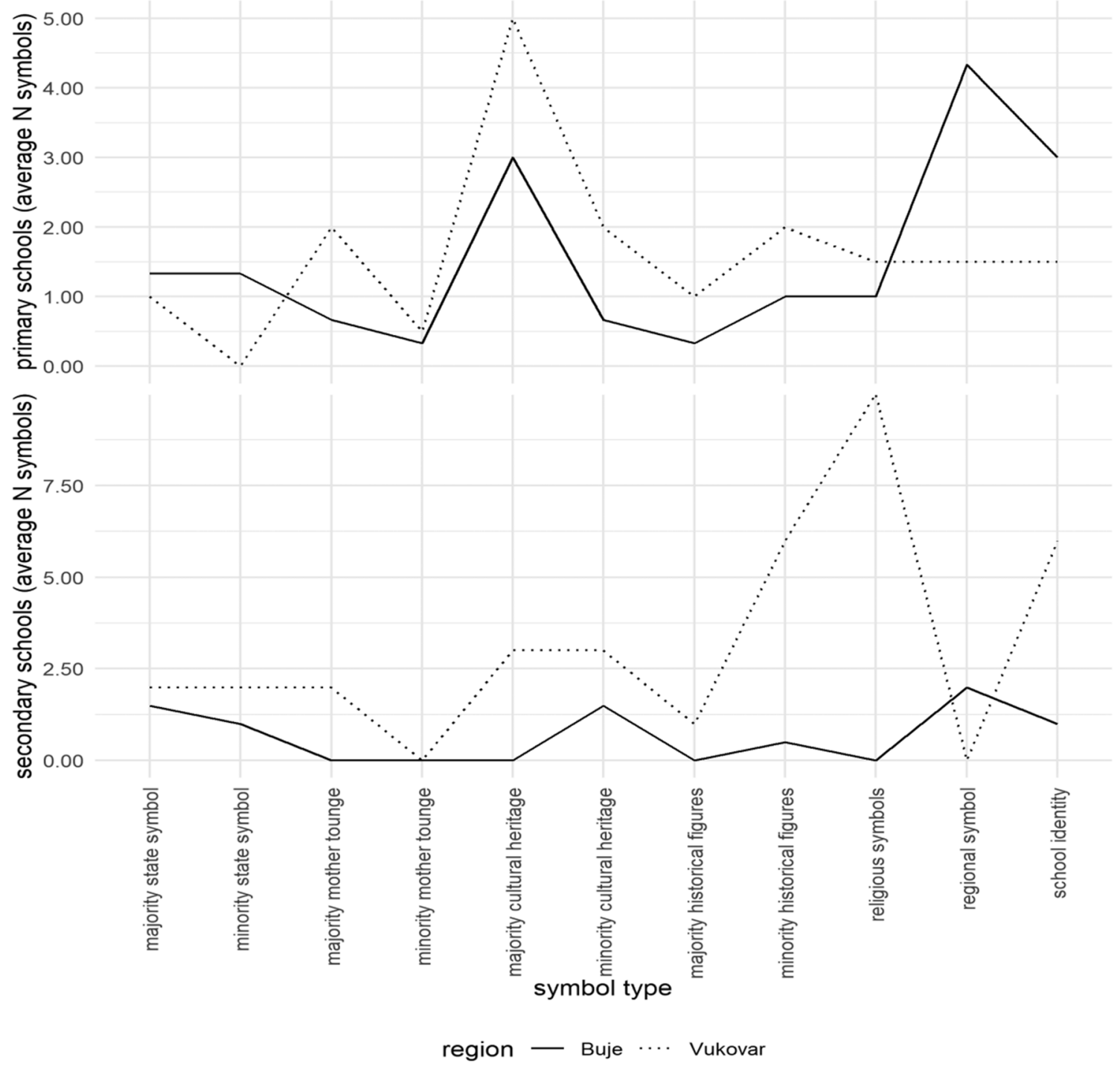

Fig. 1 Average number of specific categories of ethnic symbols per school in elementary and secondary schools in Buje and Vukovar

and minority historical figures, whereas in Buje the highest presence was found for regional identity followed by symbols of school identity and majority cultural heritage. In secondary school in Buje ethnic symbols were generally scarce, almost non-existent. The few we did find represented regional identity, school identity or minority cultural heritage. On the other hand, in Vukovar there is a very strong representation of religious symbols, minority historical figures and school identity.

We also looked for the categories of symbols where the difference between majority and minority symbols is the largest. The categories where more symbols were found in Buje than in Vukovar are regional identity, school identity and also minority state symbols in primary schools, and regional symbols in secondary schools. Taking into consideration that the number of ethnic symbols is altogether low in Buje, these findings seem even more important. On the contrary, we found much more and also much greater differences in the opposite direction. Specifically, in Vukovar there is overrepresentation of symbols related to majority mother tongue (both in primary and secondary schools), majority cultural heritage (both in primary and secondary schools), minority cultural heritage (both in primary and secondary schools), minority historical figures (especially in secondary schools), and religious symbols (the largest difference altogether, but especially in secondary schools). Symbols of school identity were overrepresented in Vukovar high school compared to high schools in Buje. However, symbols of school identity were mostly focused on the activities involving only majority pupils in Vukovar.

Altogether, the distribution of ethnic symbols over specific categories (Fig. 1) proved to be even more informative about the intergroup relations than the average number of ethnic symbols. In Vukovar the emphasis is exactly on those categories of ethnic symbols that highlight the existing differences between the groups in the community. Symbols related to mother tongue highlight differences between Croats and 
Serbs as the two nations use different scripts, Latin versus Cyrillic, and bilingual public signs in Vukovar are highly objected by the majority. Religious symbols also emphasize differences as Serbs are mostly Orthodox whereas Croats are Catholic, and religion is often emphasized as the core of identity. In contrast, in Buje the most represented symbols are those that refer to the common identity (such as regional identity and school identity). Furthermore, it seems that in harmonious context, ethnic symbols play a significant role in primary schools but in secondary schools they are no longer present on the school walls. However, in the conflicted context they are not only still present in the secondary schools but maybe even more pronounced. This may be a strategy to boost ethnic identities of both majority and minority group since the age of high schoolers is important developmental phase in investigating, developing and achieving ethnic identity (Phinney 1990). We do not argue that this strategy of "showing the symbols" is necessarily intentional; however, we do argue that it makes ethnic differences more vivid and social salient to the adolescents. Finally, it seems that the historical figures from the minority groups are overrepresented compared to famous figures from the majority group in both settings indicating that when an ingroup status is lower, group members turn to prominent, high-status ingroup members to identify with.

\section{Study 2}

In study 2 we aimed to explore whether the differences in school decorations relate to the differences in intergroup attitudes among students. Hence in focus group discussions with adolescents we explored if and to what extent children are aware of the ways in which the schools decorate the space during different holidays and celebrate them.

\section{Method}

\section{Sample}

In a series of 10 focus group discussions (4 in Buje and 6 in Vukovar) we explored how different (ethnic) holidays are celebrated in school and whether and how children perceive ethnic symbols in their schools. Altogether 30 majority and 30 minority children of age 11-18 years took part in these group discussions (see Table 1 for more details). Participants in each focus group were ethnically homogenous, i.e. either minority or majority group members.

\section{Procedure}

Social psychologists with a lot of experience in conducting focus groups moderated group discussions. During the focus group discussions, we covered various topics, but in this study the aim was to understand how students perceive ethnic symbols in schools and their importance. Therefore we focus on the following themes relating to multicultural practices and decoration of school: 1 . who and how decorates the school space during different holidays, 2 . active participation of students in decorating the school and in celebrating holidays, 3 . national holidays that are celebrated in schools, 4, additional (majority and minority) ethnic holidays celebrated in school, 5. activities connected to the School Day, and 6. the most important or the most favored holiday in school as perceived by pupils.

\section{Data Analysis}

Focus group conversations were transcribed verbatim. A thematic analysis of transcripts was conducted and for the coding phase we used Boyatzis' hybrid approach (Boyatzis 1998) to define themes and codes. Each code was assigned a label with a definition and coding example and codes followed the themes of the focus groups. All transcripts were coded by two independent researchers and then codes were compared (suggesting high inter-rater reliability) and their differences were resolved by consensus. Patterns and differences between minority and majority group members in each region were analyzed by the first author using the constant comparison technique.

\section{Results}

A cross-case analysis of similarities and differences across cases (focusing on differences between majority and minority members in the two regions) confirmed that schools' physical environment reflects community norms regarding intergroup relations and promotion of multiculturalism. In other words, data from focus groups corroborates differences between Vukovar and Buje in

Table 1 Number of participants in focus group discussions in each region with regard to gender, type of school and language of schooling

\begin{tabular}{lllllllr}
\hline & Total N & Male & Female & Primary s. & Secondary s. & Ethnic minority & Croatian \\
\hline Vukovar & 36 & 17 & 19 & 24 & 12 & 18 & 18 \\
Buje & 24 & 12 & 12 & 12 & 12 & 12 & 12 \\
\hline
\end{tabular}


the importance placed on specific (ethnic) symbols, i.e. ethnic holidays. Again, Vukovar and Buje proved to be multiethnic settings that reflect very different values about intergroup relations.

In post-conflict intergroup context (Vukovar), higher importance of ethnic holidays celebrated by one group only were reported by the students. Thus, only one group participates in decoration of the school and the outgroup is excluded, thereby contributing to the further division between the students. For Croats in Vukovar the most important holiday is the Remembrance Day of Vukovar (commemorating the sacrifice of the defenders of Vukovar and emphasizing the narrative of Croatian defenders fighting against Serbian aggressors) and for Serbs it is the St Sava's Day (the founder of the Serbian Orthodox Church). An excerpt from the focus group discussion held separately with Croatian and Serbian students from the same school shows the ethnic gap clearly. Thus, when asked about the national holidays they celebrated in school, Croatian students answered:

Remembrance day, Day of Vukovar. That day we light the candles downstairs. ( (C-F-P $)^{1}$

We even decorate the billboards in the school so that they reflect what had happened on that day. In the Homeland war. (C-M-P)Last year's 7th and 8th grade students presented to us (and we were 6th graders at the time) what had happened that day in Vukovar. (C-F-P)I mean, of course they [referring to Serbs] don't want to come on November 18th or on celebration of our Christmas, just as I wouldn't go on theirs. (C-M-S)In the group with Serbian students their answers on the same question were very different and reveal ambivalent attitudes toward common celebration of various ethnic holidays in school:We celebrate St Sava and that's about it. (S-F-S) They divide us. Croats are the first shift [morning shift] and we are always second shift. And so we have our own show. This year girls were dressed in Serbian folk costumes and greeted the guests with bread and salt. But the school walls are usually not decorated for our holiday, only during the event but it is all taken off after the event. (S-F-S)Everything is restricted to that one room, our gym. (S-M-S)But when they have their show, we attend, we go there. So I think it is not right that they ignore our show on St Sava day. Just as we support them in a way, they should support us. (S-F-S) I don't think so... I mean it is our holiday. What would

\footnotetext{
${ }^{1} \mathrm{ID}$ of a participant is given in the parenthesis indicating his/her ethnicity (CCroat, S- Serb, I - Italian), gender (F or M) and type of school (P- primary, Ssecondary school).
}

they do there if they don't even know who St Sava was and all that. (S-F-S)

At the same time, in Buje various holidays are celebrated without strong emphasis on ethnic holidays. Furthermore, the Remembrance Day of Vukovar is mentioned at school but not given a central place as is the case in Vukovar. When asked about the holidays they celebrated in school, Croatian students answered:[We celebrate] all of them. (C-F-S) We celebrate world holidays as much as our own. (C-F$\mathrm{S})$

We didn't even learn in my primary school about Croatian history of the 90s, Homeland War and such. We were always told that this is to recent to be part of the history and it was always skipped. (C-F-S)

We have also never celebrated the Remembrance Day in my primary school. I cannot say that we don't do it now in the secondary school, but we don't put much emphasis on that. (C-F-S)

Interestingly, both in Vukovar and in Buje Christmas is perceived as either the most important or the most favored holiday for everybody, regardless of ethnic group belonging, followed by the last day of school (which is often also the official School Day). However, in celebration of this holiday in Buje everybody is included, but in Vukovar, where Catholic and Orthodox Christmas are celebrated with two weeks delay, the celebration of Christmas further highlights intergroup differences.As opposed to that, in Istria majority group children exhibit a strong awareness of the other ethnic group and willingness to accommodate:

We do not emphasize national holidays as much as international [referring to Valentine's Day, Christmas, etc.], because we know that this way we shall not remind ethnic minorities that they do not originate from here (C-F-P)

\section{Study 3}

In a quantitative survey in the same schools we investigated differences in the attitude toward multiculturalism and intergroup bias (i. e. preference of the ingroup over the outgroup), as two relevant indicators of intergroup relations. We expected quantitative data to corroborate qualitative findings by showing more intergroup bias and less positive attitudes toward multiculturalism among adolescents from Vukovar than those from Istria. 


\section{Method}

\section{Sample}

A quantitative survey was administered on 522 students from the same primary and secondary schools as in the qualitative study. In Vukovar 300 students were included in the survey (176 Croats and 124 Serbs), 70 from primary and 230 from secondary schools. The age in theVukovar sample ranged from 12 to 19 , and there were more girls than boys in the classes (62\% girls). In Buje, 222 students participated in the survey (98 Croats, 116 Italians and 8 did not state their ethnicity), 55 from primary and 167 from secondary schools. The age in the Buje sample also ranged from 12 to 19 , and there were again more girls than boys in the classes (55\% girls). In both contexts the vast majority of respondents assessed their life standard as average or slightly above average $(85 \%$ in Buje and $90 \%$ in Vukovar).

\section{Instruments}

The attitude toward multiculturalism was measured by a 5 item scale adapted from our previous studies (Čorkalo and Ajduković 2008) and sample items are: "School should to take care of the rights of national minorities" and "National minorities enrich the culture of every nation". The responses were indicated on a five-point Likert-type scale ranging from 1 (highly disagree) to 4 (highly agree). Higher values indicated more positive attitude toward multiculturalism. The reliability of the scale in this research was $\alpha=.71$.

The intergroup bias was measured by asking participants to express their general attitude towards the majority and towards the relevant minority group in their community on a scale from 0 to 10 . The difference of the ratings for the ingroup and the outgroup is the indicator of ingroup bias.

\section{Procedure}

The questionnaires were administered in groups, during regular class hours. Participation was voluntary and parental permissions were obtained for students under the age of 14. All questionnaires were completed anonymously and were administered in the native tongues of the students. Ethical approval was granted by the university Institutional Review Board.

\section{Results}

In order to assess whether the difference in the presence of ethnic symbols in two multiethnic communities relates to the contextual differences in intergroup attitudes of minority and majority adolescents, we conducted two ANOVAs to
Table 2 Summary of ANOVA for multiculturalism and intergroup bias in two different social contexts

\begin{tabular}{lllll}
\hline & \multicolumn{2}{l}{ Multiculturalism } & \multicolumn{2}{l}{ Intergroup bias } \\
\hline Source & $\mathrm{F}$ & $\mathrm{p}$ & $\mathrm{F}$ & $\mathrm{p}$ \\
Context & 1.07 & .302 & 11.44 & .001 \\
Group status & 7.35 & .007 & 30.42 & .001 \\
School type & .47 & .493 & .291 & .590 \\
Context x Status & 9.27 & .002 & .001 & .983 \\
Context x School type & .001 & .977 & 4.60 & .032 \\
Status x School type & 4.87 & .028 & .21 & .645 \\
Status x Context x School type & .02 & .878 & .71 & .400 \\
Error & .25 & & 8.73 & \\
Total & 486 & & 509 & \\
\hline
\end{tabular}

determine if there is an interaction between three independent variables - context (Vukovar vs Buje), group status (majority vs minority ethnic group) and type of school (primary vs secondary) - on two dependent variables: attitudes towards multiculturalism and intergroup bias. Survey was conducted among majority and minority students from the very same schools that we observed (Table 2).

The results for multiculturalism show strong main effect of the group status $(\mathrm{F}(1,486)=7.35, p=.007)$ suggesting that minorities embrace multiculturalism much more than the majority. The analysis also yielded two significant interactions of status and context $(\mathrm{F}(1,486)=9.27, p=.002)$ and status and school type $(\mathrm{F}(1,486)=4.87, p=.028)$.

As can be seen from the Fig. 2 in Buje there are no differences between the majority and the minority group in their attitudes toward multiculturalism. Students in general equally endorse multiculturalism. In Vukovar however, there is a huge difference in the attitudes of the majority and the minority youth, with minority students having much more positive

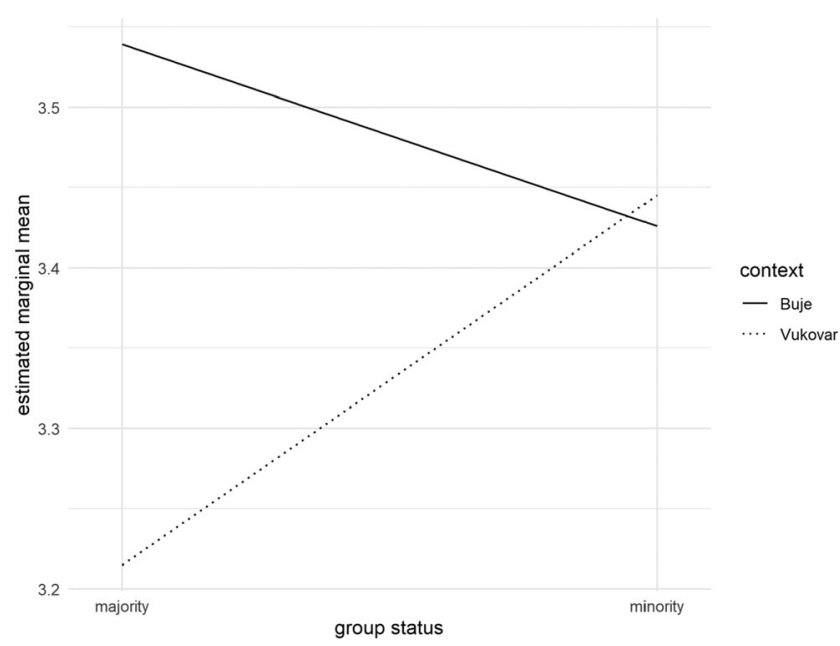

Fig. 2 Interaction of group status (majority vs minority) and context (Vukovar vs Buje) for attitude toward multiculturalism 


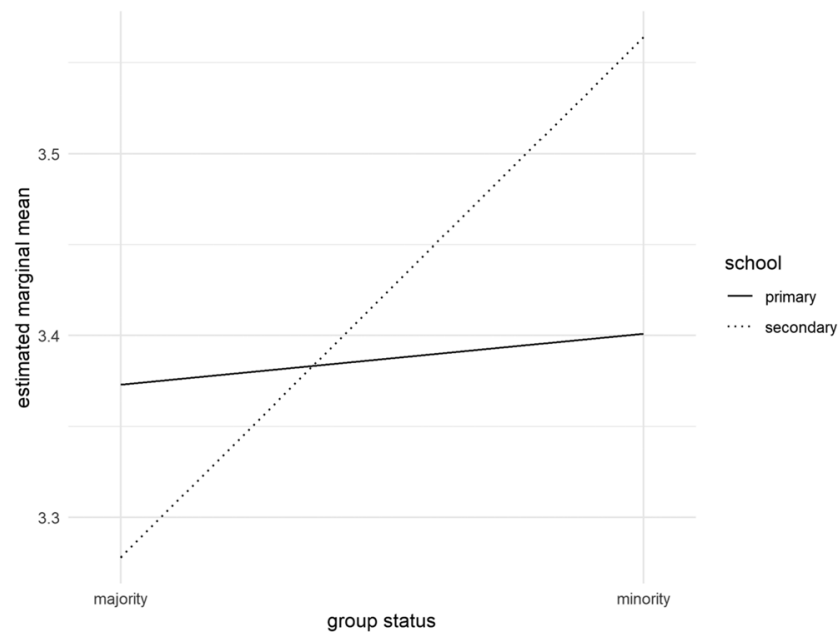

Fig. 3 Interaction of group status (majority vs minority) and school type (primary vs secondary school) for attitude toward multiculturalism

attitudes toward multiculturalism (although majority also holds positive attitudes). Fig. 3 shows that the minoritymajority attitudinal differences are much more pronounced in secondary compared to primary schools, regardless of the context.

In line with attitudes towards multiculturalism, the results for intergroup bias show strong main effect of the group status $(\mathrm{F}(1,509)=30.42, p<.001)$ corroborating stronger ingroup bias among the majority than the minority. Furthermore strong main effect of the context $(\mathrm{F}(1,509)=11.44, \mathrm{p}<.001)$ suggests that adolescents from Vukovar are more biased than adolescents from Buje. The analysis also revealed a significant interaction of type of school and context $(\mathrm{F}(1,509)=4.60$, $p=.032$ ) showing once again that the contextual differences are much more pronounced in secondary compared to primary schools (Fig. 4).

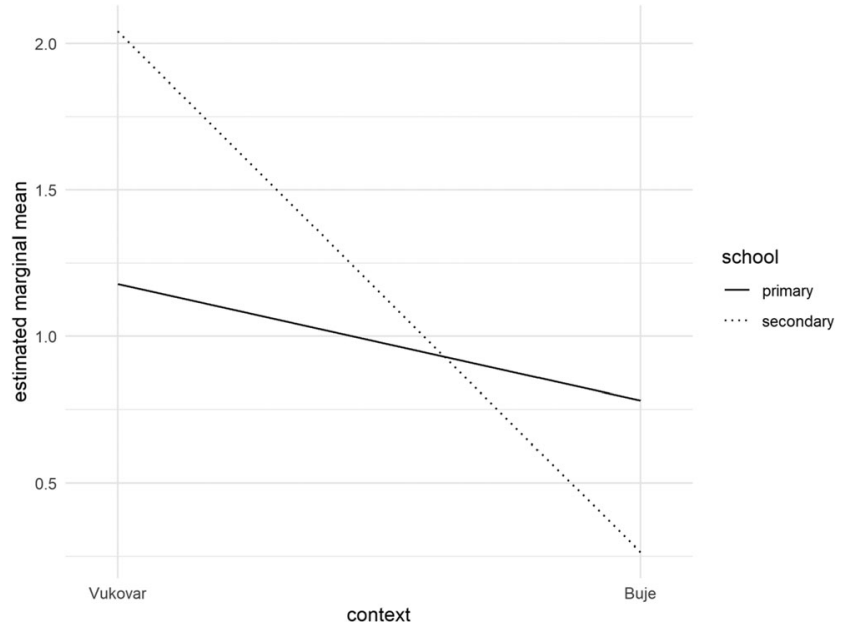

Fig. 4 Interaction of group status (majority vs minority) and context (Vukovar vs Buje) for intergroup bias

\section{General Discussion}

Schools shape and promote social values in any given society (Thornburg 1984; Berson and Oreg 2016). Results from several studies showed that a school's physical environment can promote values attached to group belonging (such as multiculturalism, regionalism or nationalism) and also be an indicator of intergroup relations. While research so far has identified various school factors influencing ethnic identity expression (ethnic composition of the school, school values of multiculturalism and school climate), the role of school physical environment is still an under-investigated topic. This article tries to fill this gap by looking closely at the role of the school's physical environment using two qualitative and one quantitative methods. In three studies we compared school practices as well as representation of ethnic symbols presented on school walls and their effects in two multiethnic contexts within the same country.

Two contexts were chosen as they differ greatly considering intergroup relation between the majority and the minority group. Whereas in one intergroup relations are harmonious and the minority group does not hold different status compared to the majority group, in the other context their relation is disturbed and still burdened with the recent intergroup conflict. At the same time, these two contexts are similar in that both are multiethnic communities where a specific minority practices their right to education on their language in separate classes or even separate schools from the majority, i.e. model A of minority schooling. This educational model allows minorities in question to preserve their identity, culture and language to the highest possible level. On the other hand, separated minority education carries with it the risk of emphasizing intergroup boundaries. On the explicit level, the benefits of such practices are usually emphasized. But what about the implicit level, i.e. the hidden curriculum? Lewis (2001) already showed that analyzing school practices can shed some more light to what messages regarding intergroup relations and values are transmitted in school.

Results of systematic observation of school space confirm that representation of ethnic symbols in schools varies across regions depending on the nature of intergroup relations in specific communities. Thus, we found extensive representation of ethnic symbols in the post-conflict settings of Vukovar whereas they are only moderately represented in the more harmonious multiethnic community. This difference, however, stems from the secondary schools in Vukovar where ethnic symbols are more elaborated and salient than in primary schools and five times more represented than in secondary schools in Buje. As Phinney's model of ethnic identity development (Phinney 1990) acknowledges significant changes during the period of adolescence, including greater abilities in cognition to contemplate ethnic identity, as well as a greater focus on one's social life, it is not surprising that in a setting 
where ethnic identity is a hot issue, stronger emphasis is put on new generations during their adolescence to shape their identities in line with expectation of their group. Our findings also fit well with Bronfenbrenner's (1994) Ecological Systems Theory emphasizing different systems (family, peers, community, and larger society) that influence one's feelings of belonging and overall affect toward ethnic groups. Thus, our findings suggest that socialization in a multiethnic community where both groups feel either victimized or discriminated has consequences on ethnic identity development of youth.

However, not only does the average number reflect the intergroup relations, but maybe even more so the distribution of ethnic symbols over specific categories. In the post-conflict setting the emphasis is put on those categories of ethnic symbols that highlight the existing differences between the ethnic groups in the community (e.g. mother tongue, religious symbols). On the contrary, in the harmonious multiethnic context the most represented symbols are those that refer to the common identity (e.g. regional or school identity). If we take into account that such hidden curriculum reflects how schools deal with the issue of multiculturalism, it seems that in the conflicted settings schools only strengthen further divisions between the groups. Interestingly, in both regions identity dualism is negotiated by promoting symbols referring to the Croatian cultural heritage and famous members of minority ethnic groups in schools physical environment. It seems that minorities in both contexts shape and enhance their ethnic identity by featuring prominent in-group historical and contemporary figures. Future research should explore whether this represents a resistance to honoring nationally significant historical figures (e.g. if symbols emphasized by the minority group are historical figures who are famous for fighting against the majority group and who majority vilifies) or a way of preserving their ethnic identity in a multiethnic setting by highlighting prominent ingroup members that were members of the same community (Hutchins 2016).

Focus groups conducted with children from the same schools we observed confirm that schools physical environment reflects community norms and values both regarding intergroup relations and promotion of multiculturalism. In line with expectations, in the post-conflict intergroup context (Vukovar) students report feeling more separated along ethnic lines when celebrations of ethnic holidays take place in school because only one group participates in decoration of the school and the outgroup is excluded, depending on the holiday. In contrast, Istrian students take a more multicultural stance and exhibit less need to put emphasis on ethnic holidays.

Finally, our quantitative data further corroborates these findings by showing stronger differences between majority and minority adolescents in their attitudes toward multiculturalism and intergroup bias in Vukovar compared to Buje. Specifically, majority adolescents in our sample exhibit stronger ingroup bias than their minority peers, and intergroup bias is stronger in Vukovar than in Buje. This difference is more pronounced in secondary schools when group identities are negotiated and formed. In the same vein, minority adolescents embrace multiculturalism more strongly than their majority peers, especially in secondary schools. These findings are also in line with Verkuyten (2010) who argued that the endorsement of multiculturalism depends on the majority - minority group status. Earlier studies on the majority group members from Vukovar and Istria also confirmed that Croats from Istria have more positive attitude on multiculturalism than Croats from Vukovar (Jelić et al. 2014). Moreover the same study showed that adults endorse multiculturalism more strongly than the children suggesting that the process of accepting social values takes place during adolescence.

Taken altogether, findings of our three studies suggest that potential differences in the ways multiculturality and group identity is promoted in schools in different regions are a reflection of interethnic relations in each context. This is in line with ecological view of environmental influences on people's attitudes and behavior and also in line with the ,ethno-symbolism "theory that suggests that ethnic group symbols can be unifying but they can also play a divisive role when conflicted ethnic groups hold different narratives of the past (Kolst 2006) depending on what they are associated with. If a symbol is perceived as belonging to one ethnic group more than another, the other group will not accept it as their own and will search for ethnic symbols they can associate with. This is exactly what we found in the town of Vukovar, i.e. a post-conflict community where there is still a lot of tension between the two ethnic groups. As already suggested by Bucholtz (2011) and Johansson and Lalander (2012) symbols can be used to highlight differences to the specific outgroup or to communicate resistance to the dominant group or the dominant narrative of the past. Indeed, different minorities within the same society might have different perspectives on how they are treated in a specific society depending on the history of the intergroup conflict, their status in the society, the changes in the minority status, and their experiences with discrimination. As argued by Verkuyten (2004), if multiculturality is indeed welcomed and the minority's ethnic identity is acknowledged and treated with respect, they are inclined to integrate into the society. However, if minority group members feel they are discriminated against, they feel threatened and thus identify more strongly with their ethnic group.

We believe that this data suggests that school plays an important role in forming intergroup attitudes among their students and school representatives and teachers should be more aware of their practices. Even some routine practices such as decorating school walls send a message to students what the school culture is and therefore should be brought to attention and re-evaluated. Furthermore, our findings also 
show that school settings can be used as a platform for sending stronger messages of intergroup tolerance and multiculturalism that children could benefit from. As this is a nonexperimental study it does not allow causal interpretation. However, it is possible that in more harmonious intergroup settings schools tend to emphasize school identity and nurture positive attitude toward multiculturalism. On the other hand, it is also possible that such school practices that put focus on common identity instead on differences between students may lead in time to a more harmonious intergroup setting. Covering school walls with photos of joint school activities or excursions and ensuring participation of all students in these activities as well as in decorating the school may be a first step towards creating more multicultural norms within school. Future (longitudinal) studies should investigate whether such changes in school practices could indeed transform intergroup climate in the school and, in time, in the wider community.

\section{Limitations of these Studies}

This is to the best of our knowledge the first study that has tried to explore the physical environment as a proxy of ingroup's messages that shape the formation of one's ethnic identity as well as intergroup relations. The findings show that school's "hidden curriculum" can be operationalized by focusing on the school's physical environment, especially on decoration practices related to ethnic holidays and commemorations. In this respect this is the first study that shows the importance of the school physical environment in shaping intergroup attitudes. However, there are several limitations of the study that future research should try to address. First, future studies should focus on the comparison of different types of schools - minority schools, majority schools and "combined" schools (that necessarily differ in the amount of intergroup contact) when investigating intergroup relations. Decorations in school, especially during ethnic holidays, may differ greatly among these three types of schools. Furthermore, qualitative methods do not allow rigorous statistical analyses and hence our data is largely descriptive in nature. Even though we included two qualitative and combined them with quantitative data from the same schools, which makes this study unique, future studies should focus on directly including results of the qualitative analysis in quantitative dataset as this would allow for more nuanced analyses and opportunity to tackle the complex nature of the impact of such hidden curriculum on children' intergroup relations. Also, our sample is relatively small and future research would benefit from involving a significantly larger number of participants so that the results could be generalized. Finally, the findings obtained in this study should be replicated on other minority groups and in different multiethnic contexts to gain a clearer perspective of what are the characteristics of a community or a context that are crucial for shaping intergroup relations.

\section{Conclusion}

In multiethnic communities, ethnic identification in school is promoted via school physical environment. School walls are typically decorated by symbols of cultural heritage, famous in-group figures, religious symbols and signs and inscriptions in the language of specific ethnic groups. As we hypothesized, representation of ethnic symbols varies across regions depending on the nature of intergroup relations in specific communities.In harmonious intergroup context multiculturality is promoted by emphasizing regional and school identity, and giving space to ethnic symbols of majority and minority groups, thus forming a multiethnic identity (such as Istrian identity). However, in a post-conflict intergroup setting we found extensive representation of symbols related to intergroup differences. Results of focus groups and the quantitative survey confirm that schools' physical environment reflects intergroup relations in the community, is recognized by students and hence leads to further deepening of intergroup boundaries. Specifically, greater differences between majority and minority adolescents in their attitudes toward multiculturalism and intergroup bias were found in postconflict Vukovar than in the more harmonious Istria. As expected, minority adolescents embrace multiculturalism more strongly than their majority peers, especially in secondary schools. In the same vein, adolescents from Vukovar exhibit stronger ingroup bias than their peers from Buje, and this difference is again more pronounced in secondary schools. We call for school practices that put focus on common identity instead of differences between the two ethnic groups in hope that this might result in more harmonious multiethnic communities.

Acknowledgments The authors would like to thank Tea Pavin Ivanec, Lana Pehar and Jasmina Tomašić Humer for their contributions in data collection, i.e. systematic observation, focus groups and coding.

The research for this paper was financially supported by the Croatian Science Foundation [grant no. 2014-09-4499].

\section{Compliance with Ethical Standards}

The IRB of the Department of Psychology at the University of Zagreb approved the study. Participation was voluntary, informed consent was obtained from all participants and additionally parental permissions were obtained for students under the age of 14 .

Conflict of Interest The authors declare that they have no conflict of interest. 
Open Access This article is licensed under a Creative Commons Attribution 4.0 International License, which permits use, sharing, adaptation, distribution and reproduction in any medium or format, as long as you give appropriate credit to the original author(s) and the source, provide a link to the Creative Commons licence, and indicate if changes were made. The images or other third party material in this article are included in the article's Creative Commons licence, unless indicated otherwise in a credit line to the material. If material is not included in the article's Creative Commons licence and your intended use is not permitted by statutory regulation or exceeds the permitted use, you will need to obtain permission directly from the copyright holder. To view a copy of this licence, visit http://creativecommons.org/licenses/by/4.0/.

\section{References}

Aldridge, J. M., Ala'i, K. G., \& Fraser, B. J. (2016). Relationships between school climate and adolescent students' self-reports of ethnic and moral identity. Learning Environments Research, 19(1), 1-15.

Ali, F., \& Amin, M. (2014). The influence of physical environment on emotions, customer satisfaction and behavioural intentions in Chinese resort hotel industry. J. Global Business Advancement, 7(3), 249-266.

Berson, Y., \& Oreg, S. (2016). The role of school principals in shaping children's values. Psychological Science, 27(12), 1539-1549.

Billig, M. (1995-2004). Banal nationalism. London: Sage.

Bisin, A., Patacchini, E., Verdier, T., \& Zenou, Y. (2016). Bend it like Beckham: Ethnic identity and integration. European Economic Review, 90, 146-164.

Boyatzis, R. E. (1998). Transforming qualitative information: Thematic analysis and code development. Thousand Oaks: Sage.

Brewer, M. B. (1991). The social self: On being the same and different at the same time. Personality and Social Psychology Bulletin, 17(5), $475-482$.

Brill, M. (1992). How design affects productivity in settings where officelike work is done. J. Health Car. Design, 4, 11-16.

Brill, M., Margulis, S. M., \& Konar, E. (1985). Using office design to increase to increase productivity. Buffalo, NY: BOSTI and Westinghouse Furniture Systems.

Bronfenbrenner, U. (1994). Ecological models of human development. In International Encyclopedia of Education (Vol. 3, 2nd ed.). Oxford: Elsevier.

Brown, C. S. (2017). School context influences the ethnic identity development of immigrant children in middle childhood. Social Development, 26(4), 797-812.

Brown, C. S., \& Bigler, R. S. (2002). Effects of minority status in the classroom on children's intergroup attitudes. Journal of Experimental Child Psychology, 83(2), 77-110.

Bucholtz, M. (2011). White kids: Language, race, and styles of youth identity. Cambridge: Cambridge University Press.

Carnegie, M. A., Bauman, A., Marshall, A. L., Mohsin, M., WestleyWise, V., \& Booth, M. L. (2002). Perceptions of the physical environment, stage of change for physical activity, and walking among Australian adults. Research Quarterly for Exercise and Sport, 73(2), $146-155$.

Chu, S. (2003). Cross-cultural comparison of the perception of symbols. Journal of Visual Literacy, 23, 69-80.

Clements-Croome, D. (Ed.). (2000). Creating the productive workplace. London: E \& FN Spon.

Constantin, A. A., \& Cuadrado, I. (2019). Perceived intergroup competition and adolescents' behavioural intentions toward minorities: The role of threat, stereotypes and emotions. Current Psychology. https://doi.org/10.1007/s12144-019-00297-8.
Čorkalo, B. D., \& Ajduković, D. (2008). Promjene međuetničke diskriminacije u djece i međuetnički stavovi i ponašanja njihovih roditelja [changes of children's discrimination tendencies and parental intergroup attitudes and behaviors]. Ljetopis socijalnog rada, 15(3), 377-400.

Čorkalo Biruški, D., \& Ajduković, D. (2007). Separate schools - A divided community: The role of school in post-war social reconstruction. Review of Psychology, 14, 93-108.

Čorkalo Biruški, D., \& Ajduković, D. (2009). Od dekonstrukcije do rekonstrukcije traumatizirane zajednice: Primjer Vukovara [from deconstruction to reconstruction of a traumatized community: The example of Vukovar]. Revija za socijalnu politiku, 16(1), 1-24.

Čorkalo Biruški, D., \& Ajdukovic, D. (2012). Parallel worlds of divided community: Time does not make much difference. In O. Simić, Z. Volčič, \& C. R. Philpot (Eds.), Peace psychology in the Balkans: Dealing with a violent past while building peace (pp. 177-198). New York: Springer.

Čorkalo Biruški, D., Jelić, M., Pavin Ivanec, T., Pehar, L., Uzelac, E., Rebernjak, B. i Kapović, I. (2019). Obrazovanje nacionalnih manjina i međuetnički stavovi u Hrvatskoj: Stanje, izazovi, perspektive. [Minority education and interethnic attitudes in Croatia: State, challenges, perspectives.] Zagreb: Friedrich Ebert Stiftung.

Davis, T. (1984). The influence of the physical environment in offices. Academy of Management Journal, 9(2), 271-283.

de Regt, S. (2018). On the causal relationship between participation in national commemorations and feelings of national belonging. Ethnic and Racial Studies, 41(9), 1710-1727.

Dolden, M., \& Ward, R. (1986). The impact of the work environment on productivity: Proceedings of a workshop. Washington, DC: National Science Foundation and Architectural Research Centers Consortium.

Donohue, D, K. (2020). Religiosity and multicultural experiences predict cultural values in college students. Current Psychology, https://doi. org/10.1007/s12144-019-00590-6.

Gubbels, J. S., Kremers, S. P. J., van Kann, D. H. H., Stafleu, A., Candel, M. J. J. M., Dagnelie, P. C., Thijs, C., \& de Vries, N. K. (2011). Interaction between physical environment, social environment, and child characteristics in determining physical activity at child care. Health Psychology, 30(1), 84-90.

Habib, F., \& Khastoo, M. (2014). An analytical approach to the impact of urban physical aspects on culture and behavior. International Journal of Architecture and Urban Development, 4(1), 17-24.

Huer, M. B. (2000). Examining perceptions of graphic symbols across cultures: Preliminary study of the impact of culture/ethnicity. Augmentative and Alternative Communication, 16(3), 180-185.

Hutchins, R. D. (2016). Nationalism and history education: Curricula and textbooks in the United States and France. New York: Routledge.

Ilozor, D. B., Love, P. E. D., \& Treloar, G. (2002). The impact of work settings on organisational performance measures in built facilities. Facilities., 20(1-2), 61-67.

Isik-Ercan, Z. (2014). Being Muslim and American: Turkish-American children negotiating their religious identities in school settings. Race Ethnicity and Education, 18(2), 225-250.

Jaskulowski, K. (2016). The magic of the national flag. Ethnic and Racial Studies, 39(4), 557-573.

Jelić, M., Čorkalo Biruški, D., \& Ajduković, D. (2014). Ideološki stavovi većinske grupe u dvije višeetničke sredine [ideological attitudes of majority groups in two multiethnic environments]. Revija za socijalnu politiku, 21(1), 19-41.

Jelić, M., Uzelac, E., \& Čorkalo Biruški, D. (2020). Intergroup threat as a mediator of ethnic identification and intergroup orientations. Journal of Language and Social Psychology, 39(4), 534-550. 
Johansson, T., \& Lalander, P. (2012). Doing resistance: Youth and changing theories of resistance. Journal of Youth Studies, 15(8), $1078-1088$

Kolst, P. (2006). National symbols as signs of unity and division. Ethnic and Racial Studies, 29(4), 676-701.

Kornfeind, L. (2001). Velikani. Novi glas: Časopis hrvatskog akademskog kluba., 2, 4-5.

Kymlicka, W. (1995). Multicultural citizenship: A liberal theory of minority rights. Oxford: Oxford University Press.

Lee, S. Y. (2006). Expectations of employees toward the workplace and environmental satisfaction. Facilities, 24(9/10), 343-353.

Lee, S. Y., \& Brand, J. L. (2005). Effects of control over workspace on perceptions of the work environment and work outcomes. Journal of Environmental Psychology, 25(3), 323-333.

Lewis, A. E. (2001). There is no race" in the schoolyard: Color-blind ideology in an (almost) all-white school. American Educational Research Journal, 38(4), 781-811.

McGuire, D. \& McLaren, L. (2007). The impact of physical environment on employee commitment in call centres: The mediating role of employee well-being. Presented at the academy of human resource development conference, Indianapolis, Indiana, 1st- 4th march 2007.

Mesic, M., \& Baranovic, B. (2005). National minority education in Croatia. In N. Genov (Ed.), Ethnicity and educational policies in South Eastern Europe (pp. 64-68). Muenster: Lit Verlag.

Mitchell McCoy, J., \& Evans, G. W. (2002). The potential role of the physical environment in fostering creativity. Creativity Research Journal, 14(3-4), 409-426.

Newsham, G., Veitch, J., Charles, K., Marquardt, C., Geerts, J., Bradley, J., Shaw, C. \& Reardon, J. (2004). Environmental satisfaction in open-plan environments: 4. Relationships Between Physical Variables. web page: http://nparc.cisti-icist.nrc-cnrc.gc.ca/npsi/ctrl? lang=en.

Oksanen, K., \& Ståhle, P. (2013). Physical environment as a source for innovation: Investigating the attributes of innovative space. Journal of Knowledge Management, 17(6), 815-827.

Phinney, J. S. (1990). Ethnic identity in adolescents and adults: A review of research. Psychological Bulletin, 108(3), 499-514.

Plaut, V. C., Markus, H. R., Treadway, J. R., \& Fu, A. S. (2012). The cultural construction of self and well-being: A tale of two cities. Personality and Social Psychology Bulletin, 38(12), 1644-1658.
Rivas-Drake, D., Hughes, D., \& Way, N. (2009). A preliminary analysis of associations among ethnic-racial socialization, ethnic discrimination, and ethnic identity among urban sixth graders. Journal of Research on Adolescence, 19(3), 558-584.

Ščukanec, A. (2015). In search of identity: The Burgenland-Croatian perspective. Časopis za hrvatske studije, 10(1), 35-56.

Smith, A. D. (2009). Ethno-symbolism and nationalism: A cultural approach. New York: Routledge.

Stallworth, O. E., \& Kleiner, B. H. (1996). Recent developments in office design. Facilities, 14(1), 34-42.

Szubielska, M., Imbir, K., \& Szymańska, A. (2019). The influence of the physical context and knowledge of artworks on the aesthetic experience of interactive installations. Current Psychology. https://doi. org/10.1007/s12144-019-00322-w.

Thornburg, H. D. (1984). Introduction to Educational Psychology. New York: West Publishing Company.

Trako Poljak, T. (2016). Hrvatski simbolički identitet: Značenja nacionalnih simbola iz perspektive hrvatskih građana. [Croatian symbolic identity: Meaning of national symbol from the perspective of Croatian citizens]. Zagreb, TIM Press.

Turner, J. C., Oakes, P. J., Haslam, S. A., \& McGarty, C. (1994). Self and collective: Cognition and social context. Personality and Social Psychology Bulletin, 20(5), 454-463.

Verkuyten, M. (2004). Ethnic identity and social context. In M. Bennett \& F. Sani (Eds.), The development of the social self (pp. 189-216) (pp. 189-216). New York, NY.

Verkuyten, M. (2010). Multiculturalism and tolerance: An intergroup perspective. In R. J. Crisp (Ed.), Social issues and interventions. The psychology of social and cultural diversity (p. 147-170) Wiley-Blackwell.

Vischer, J. C. (2007). The effects of the physical environment on job performance: Toward a theoretical model of workspace stress. Stress and Health, 23, 175-184.

Wiltgren, L. K. (2014). Youth using national symbols in constructing identities. Journal of Youth Studies, 17(3), 308-323.

Publisher's Note Springer Nature remains neutral with regard to jurisdictional claims in published maps and institutional affiliations. 